\title{
Mahatsak txerritzen
}

Oier Aizpurua-Olaizola*, Asier Vallejo, Maitane Olivares, Patricia Navarro, Nestor Etxebarria eta Aresatz Usobiaga

Kimika Analitikoa Saila, Euskal Herriko Unibertsitatea (UPV/EHU)

*oier.aizpurua@ehu.eus

DOI: $10.1387 /$ ekaia.14524

Laburpena: Lan honetan, optimizatu egin da bi urratseko jariakin gainkritikoaren bidezko erauzketa (SFE Supercritical Fluid Extraction), ardo hondakinetatik konposatu bioaktiboak lortzeko. Ondorioz, lortu da lehen urratsean gantz azidoak soilik eta bigarren urratsean polifenolak soilik erauztea. Polifenolek egonkortasun eskasa dute ordea. Hori dela eta, zurrusta-bibrazio bidezko mikrokapsularatzea (VNM Vibration Nozzle Microencapsulation) erabili da 150 eta $300 \mu \mathrm{m}$-ko zurrustekin kaltzio-alginatozko eta kaltzio-alginato-kitosanezko tamaina ezberdinetako polifenolen mikrokapsulak eratzeko. Prozesu horretan eragina duten aldagaiak optimizatu, kapsulak sortu eta haien egonkortasuna aztertu da 6 hilabetetan zehar hainbat kontserbazio-baldintzatan $\left(4^{\circ} \mathrm{C}\right.$-ra ilunpean eta giro-tenperaturan ilunpean eta argipean). Ondorioz, ikusi da kapsulatutako polifenolen egonkortasuna baldintza guztietan kapsulatu gabeena baino askoz ere handiagoa dela.

Hitz-gakoak: Ardo-hondakinak, Jariakin gainkritikoaren bidezko erauzketa, mikrokapsularatzea, gantz azidoak, polifenolak.

Abstract: In this study supercritical fluid extraction (SFE) has been successfully applied to a sequential fractionation of fatty acids and polyphenols from wine wastes. Unfortunately, polyphenols have a poor long-term stability, so they were encapsulated through vibration nozzle microencapsulation using two nozzles of 150 and $300 \mu \mathrm{m}$ and sodium alginate and sodium-alginate-chitosan as polymer. Long-term stability of the created microcapsules was studied for 6 months taking into account different storage conditions: at $4{ }^{\circ} \mathrm{C}$ in darkness, and at room temperature in darkness and in presence of light. Encapsulated polyphenols were found to be much more stable compared to free polyphenols regardless the encapsulation procedure and storage conditions.

Keywords: Wine wastes, supercritical fluid extraction, microencapsulation, fatty acids, polyphenols. 
Oier Aizpurua-Olaizola, Asier Vallejo, Maitane Olivares, Patricia Navarro, Nestor Etxebarria, Aresatz Usobiaga

\section{SARRERA}

Bukatu zen bi gauza batera emakumeek soilik egin zitzaketen garaia. Gaur egun tximistaren abiaduran bizi gara gehientsuonok, ia geure itzalak aurreratuko gaituen beldurrez, eta noski, gorputzari aireaz gain zerbait eman behar diogula zeharo ahaztuta. Ondorioz, janari lasterrak eta industrian prozesatutako elikagaiak gure eguneroko ogi bilakatu dira, baita horiek duten balio nutrizionalaren galera konpentsatzeko gehigarrien beharra ere. Gehigarri horien artean gantz azido asegabeak eta polifenolak aipatu nahi ditugu [1]

Polifenolek ahalmen antioxidatzaile handia dute; horri esker erradikal askeak neutralizatzeko gai dira, arrisku txikiagoko konposatuak emanez [24]. Gaitasun hori dela eta, konposatu hauek egokiak dira hainbat aplikaziotarako, hala nola hanturak tratatzeko [5], minbiziaren gisako endekapenezko gaixotasunetarako [6-7] edo kosmetikan zahartzearen aurkako tratamenduetarako [8-9]. Bestalde, nootropiko bezala zerrendatuak daude, garunean oroimena, arreta eta motibazioa gisako funtzioak bultzatzen laguntzen baitute [10].

Gantz azidoak 3 taldetan sailkatuta daude: poliasegabeak (PUFA), monoasegabeak (MUFA) eta asetuak (SAFA). Azido linoleikoaren gisako PUFAk oso garrantzitsuak dira gaixotasun kardiobaskularren prebentzioan [11-12]; azido oleikoa bezalako MUFAk aldiz funtsezkoak dira odoleko triazilglizerol eta kolesterol mailak jaisteko eta ondorioz minbizien prebentziorako [13-14]. Azido estearikoa edo palmitikoa bezalako SAFAk alderantzizko efektuaren erantzule dira ordea, odoleko kolesterol maila igotzen baitute eskuarki [15].

Agroindustriako hondakinen inguruko interesa haziz joan da azken urteetan, balio erantsi handiko albo produktuen iturri garrantzitsu izan baitaitezke. Ildo horretatik, ardo-ekoizpeneko hondakinen ustiapena aukera bikaina izan daiteke. Izan ere, bertan aurkitzen diren gantz azido asegabeen eta polifenolen kontzentrazioa altua izateaz gain, sortzen den hondakin kopurua izugarria da baina ustiapena, berriz, mugatua [16].

Konposatu bioaktiboak erauzterako eta jakiak prozesatzeko orduan aukerarik egokienetako bat da jariakin gainkritikoen bidezko erauzketa. SFE jariakin gainkritikoen ezaugarrietan oinarritzen da. Gas bat presio eta tenperatura kritikotik haratago jartzen denean egoera gainkritiko batera iritsi daiteke, eta hala, likidoen eta gasen arteko ezaugarriak hartzen ditu. Likidoen antzeko dentsitatea dute eta hargatik disolbatzaile onak dira; bestalde, gasen likatasuna eta mugikortasuna dutenez, material solidoaren poroetara hobeto heltzen dira eta erauzketak azkarrago lortzen dira. Erauzketak egiteko hainbat disolbatzaile erabil daitezke; dena den, karbono dioxidoa erabiltzea da ohikoena, hainbat abantaila garrantzitsu aurkezten baititu [17-19]. Batetik inertea geldoa eta ingurumenarentzat garbia izateaz gain erauzketa-tenperatura eta presio baxuetan gauzatzea ahalbidetzen duenez baldintza gogorrekiko 
sentikorrak diren konposatuen degradatzea saihesten du. Bestetik, lortzen diren erauzkinak purutasun altukoak dira eta ondorioz, elikagaien industrian arazo gabe erabil daitezke. Erauzketa eskala industrialean egiteko eragozpenik ez dago gainera. Hortaz gain, nahiz eta $\mathrm{CO}_{2}$ disolbatzaile apolarra izan, etanola edo metanolaren gisako albo disolbatzaile polar bat gehitu dakioke, eta horrela, modu horretan lortzen da polartasun ezberdineko konposatuak elkarrengandik bereizita erauztea, lehenik apolarrak $\mathrm{CO}_{2}$ soilik erabiliz eta ostean polarrak albo-disolbatzailea gehituz [20-21].

Zoritxarrez, polifenolak erraz degrada daitezke argiaren, tenperaturaren, oxigenoaren eta entzimen aktibitateen ondorioz [22]. Bestalde, sarritan ez dira oso bioeskuragarriak, uretan disolbagarritasun baxua baitute eta jariakin biologikoetan dagoen baldintza alkalinoetan ezegonkorrak baitira gainera [23]. Hortik dator konposatu hauek kapsulatu beharra, modu horretan egiazki lortzen baita konposatuen egonkortasuna eta bioeskuragarritasuna hobetzea [23-24].

Mikrokapsulatzeko teknika ugari daude. Horien artean aurkitzen da zurrusta-bibrazio bidezko mikrokapsularatzea, teknika erraza delako, eta industrian erabilgarria eta konposatu hidrofilikoentzat egokia [25]. Teknika horretan, agente kapsulatzailearekin nahasten dira kapsulatu nahi diren konposatuak eta nahastearen fluxu laminar bat zulo txiki batetik igaroarazten da, aplikaturiko bibrazioari esker tanta nimiñoak osatuz. Tentsio bat ezarrita, tanta horiek dispertsatu egiten dira eta gogortze-disoluziora erorita mikrokapsulak osatzen dira (1. irudia).

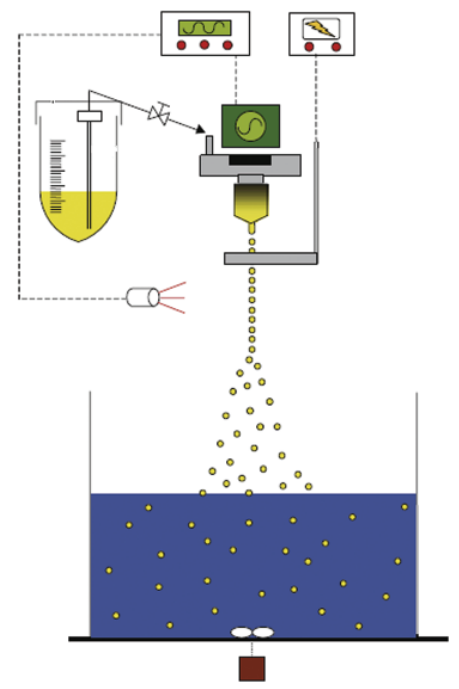

1. irudia. Erabilitako kapsulatze-sistemaren azalezko azalpena (Buchi B-390). 
Oier Aizpurua-Olaizola, Asier Vallejo, Maitane Olivares, Patricia Navarro, Nestor Etxebarria, Aresatz Usobiaga

Kapsulatzaile agente ohikoena alginatoa da. Alginatoa alga marroietatik lortzen da eta kaltzio katioiekin erreakziona dezaketen talde karboxiliko ugari ditu; modu horretan konposatu aktiboak babes ditzakeen gel egonkorrak osatzen ditu [26]. Hori dela eta, agente gisa alginatoa erabiltzen denean, kaltzio klorurozko disoluzioa erabili ohi da gogortze-disoluzio gisa.

Kapsulen egonkortasuna are gehiago hobetzeko aukera gehigarri bat da alginatoarekin batera kitosana bezalako agente egonkortzaile bat erabiltzea [27]. Kitosana karramarroen kanpo eskeletoetatik erdiesten da eta elektroi-emaile gisa diharduten $-\mathrm{OH}$ eta $-\mathrm{NH}_{2}$ talde ugari ditu. Ondorioz, alginatoak eta kitosanak bateragarritasun bikaina dute, elkarrekin erreakziona baitezakete, dituzten aurkako kargei esker [28].

Lan honetan optimizatu egin da SFE bidezko metodo bat, ardo hondakinetatik gantz azidoak eta polifenolak elkarrengandik berezita erauzi ahal izateko.

Bestalde, optimizatu egin da polifenolen egonkortasuna hobetzeko VNM bidezko mikrokapsularatzea ere. Osatutako mikrokapsulen egonkortasuna aztertu da 6 hilabetean zehar, kontserbazio-baldintza ezberdinetan.

\section{JARIAKIN GAINKRITIKOAREN BIDEZKO ERAUZKETA}

\subsection{Gantz azidoen eta polifenolen erauzketaren optimizazioa}

Gantz azidoak ezpolarrak dira, baina polifenolak ordea polarrak. Ezberdintasun horretan oinarritzen da diseinatutako erauzketa konposatu bakoitza bereizita erauzteko. Lehenik, $\mathrm{CO}_{2}$ soilik erabiliz ardo hondakinetatik gantz azidoak erauztea lortu nahi da, eta ostean albo disolbatzaile gisa metanola gehituz polifenolak erauztea. Ahalik eta konposatu gehien erauzteko, beharrezkoa da ordea bi urrats hauek bata bestearen atzetik egin aurretik bakoitza bere aldetik optimizatzea. Horretarako, lehendabizi tenperatura, $\mathrm{CO}_{2}$-fluxua, presioa eta erauzketa-denboraren eragina aztertu dira urrats bakoitzean, eta polifenolen kasuan baita gehitutako albo-disolbatzailearen ehunekoa ere.

Optimizazioak diseinu konposatu zentrala (CCD Central Composite Design) erabiliz gauzatu dira, 4 aldagai eta 27 laborategi-saioko matrize banaren bidez erauzketa maximoa gertatzen den gainazal-erantzunak erdietsiz hain zuzen ere. Polifenolen kasuan erauzketa-denbora diseinutik kanpo utzi da eta optimizazioaren ostean aztertu da erauzketa jarraituen bidez.

Gainazal-erantzunak lortzeko emaitza gisa masa-espektrometriari akoplaturiko gas-kromatografia bidez (GC-MS) lortutako gantz azidoen kon- 
tzentrazioak erabili dira gantz azidoen kasuan; polifenolen kasuan aldiz, Folin-Ciocalteu [29] metodoaren bidez lortutako polifenolen osoko kontzentrazioa erabili da. 1. taulan ikus daitezke aztertutako tarteak eta erdietsitako balio optimoak.

1. taula. SFE erauzketako 2 urratsetan aztertutako tarteak eta erdietsitako balio optimoak.

\begin{tabular}{lcccr}
\hline \multicolumn{1}{c}{ Aldagaiak } & $\begin{array}{c}\text { Aztertutako tartea Gantz } \\
\text { azidoak }\end{array}$ & $\begin{array}{c}\text { Balio } \\
\text { optimoak }\end{array}$ & $\begin{array}{c}\text { Aztertutako tartea } \\
\text { Polifenolak }\end{array}$ & $\begin{array}{c}\text { Balio } \\
\text { optimoak }\end{array}$ \\
\hline Tenperatura $\left({ }^{\circ} \mathrm{C}\right)$ & $35-55$ & 35 & $35-55$ & 35 \\
Fluxua $(\mathrm{mL} / \mathrm{min})$ & $1-2$ & 2 & $1-2$ & 2 \\
Presioa (bar) & $103-253$ & 253 & $103-253$ & 103 \\
Denbora (min) & $5-79$ & 5 & Erauzketa jarraituak & 5 \\
Metanola $(\%)$ & - & - & $0-40$ & 40 \\
\hline
\end{tabular}

Gantz azidoen erauzketan, ikusi da $\mathrm{CO}_{2}$-fluxua eta presioa direla estatistikoki eragina duten aldagaiak. Hala, aldagai horiek balio altuetan finkatu dira eta denbora eta tenperatura aldagaiak aldiz balio baxuetan, azken hauek ez baitiote prozesuari eragiten.

Polifenolen kasuan $\mathrm{CO}_{2}$ fluxua eta erabilitako albo disolbatzailearen portzentaia izan dira eragileak. Ondorioz, horiek balio altuetan finkatu dira eta eragiten ez duten aldagaiak, kasu honetan tenperatura eta presioa balio baxuetan zehaztu dira. Erauzketa jarraituetan, ikusi da 5 minutuko erauzketak aski direla.

\subsection{Bi urratseko erauzketaren balioztatzea}

Behin urrats bakoitza bere aldetik optimizatuta, bata bestearen atzetik aplikatu dira ardo hondakinetatik lehenik gantz azidoak eta ostean polifenolak erauzi ahal izateko. Ardo hondakinetan gehien agertzen diren 4 konposatu nagusiak kuantifikatu dira talde bakoitzean, gantz azidoen kasuan GC-MS bidez eta polifenolen kasuan fragmentazio bikoitzeko masa-espektometriari akoplaturiko eraginkortasun handiko likido kromatografia bidez (LC-MS/MS). Lorturiko emaitzak 2. irudian laburbiltzen dira.

2. irudian ikus daiteke, ez dagoela ezberdintasunik bi urratsak jarraian egitearen edo bakoitza bere aldetik egitearen artean. Hala, lehen urratsean $\mathrm{CO}_{2}$ soilik erabiliz, gantz azido ia denak erauztea lortu da inongo polifenolik erauzi gabe; ostean, metanola gehituta polifenol guztiak ezauzi dira bigarren urratsean. 
Oier Aizpurua-Olaizola, Asier Vallejo, Maitane Olivares,

Patricia Navarro, Nestor Etxebarria, Aresatz Usobiaga
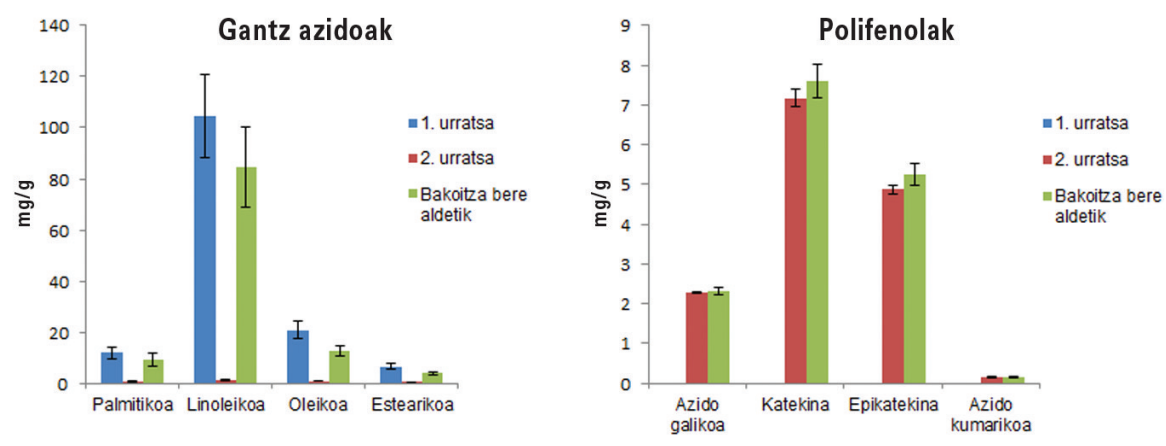

2. irudia. Gantz azidoen eta polifenolen kontzentrazioak lehen urratsean $\left(\mathrm{CO}_{2}\right.$ soilik), lehenengoaren jarraian bigarren urratsa gauzatzean $\left(\mathrm{CO}_{2}+\right.$ metanola $)$ eta urrats bakoitza bere aldetik egitean (alde batetik $\mathrm{CO}_{2}$ soilik eta beste aldetik $\mathrm{CO}_{2}+$ metanola soilik), dagokien desbiderapen estandarrekin $(\mathrm{n}=3)$.

\section{POLIFENOLEN KAPSULARATZEA}

\subsection{Polifenolen mikrokapsularatzearen optimizazioa}

Eragile gerta daitezkeen 4 aldagai nagusi daude, 1. irudian ikusgai dagoen zurrusta-bibrazioaren bidezko mikrokapsularatzearen bidez kapsulak eratzerako orduan: agente kapsulatzailearen eta kapsulatu nahi diren konposatuen nahastearen fluxu laminarra osatzeko ezarririko presioa, fluxua banakako tanta nimiñoetara aldatzen duen bibrazioaren maiztasuna, tantatxo hauek banatzeko aplikaturiko tentsioa, eta gogortze disoluziora dagoen distantzia. Bestalde, sisteman jarritako zurrustaren arabera hainbat tamainatako mikrokapsulak osatu daitezke, baina zurrusta bakoitzarentzat aldagaien balio optimoak ezberdinak izango dira ordea. Lan honetan 150 eta $300 \mu \mathrm{m}$-ko zurrustak erabili dira mikrokapsulak osatzeko, komenigarria baita ostean emango zaien aplikazioaren arabera tamaina bateko edo besteko mikrokapsulak izatea. Zurrusta bakoitzarekin lan egiteko baldintza egokienak erdiesteko, 27 laborategi-saioko matrize bana erabili da aurreko kasuan bezala. Gainazal-erantzunak lortzeko 3 erantzun hartu dira kontuan: ondo eratutako kapsula biribilen ehunekoa, gaizki eratutako kapsula ezbiribilen ehunekoa eta elkarri itsatsiriko kapsulen ehunekoa.

Hala, lortu nahi izan da ondo eratutako kapsulen kopurua maximoa izatea eta gaizki eratutakoena minimoa izatea. 2. taulan ikus daitezke, diseinuan aztertutako tarteak eta erdietsitako balio optimoak.

Baldintza optimoekin erdietsitako mikrokapsula hezeen batazbesteko tamaina $278 \pm 8 \mu \mathrm{m}$-koa izan da $150 \mu \mathrm{m}$-ko zurrusta erabiliz, $300 \mu \mathrm{m}$-ko zurrustaren kasuan aldiz $600 \pm 90 \mu \mathrm{m}$-koa (3. irudia) 
2. taula. 150 eta $300 \mu \mathrm{m}$-ko zurrustekin kapsula optimoak osatzeko aztertutako aldagaien tarteak eta balio optimoak

\begin{tabular}{lcccc}
\hline \multicolumn{1}{c}{ Aldagaiak } & $\begin{array}{c}\text { Aztertutako tartea } \\
150 \mu \mathrm{m}\end{array}$ & $\begin{array}{c}\text { Balio } \\
\text { optimoak }\end{array}$ & $\begin{array}{c}\text { Aztertutako tartea } 300 \\
\mu \mathrm{m}\end{array}$ & $\begin{array}{c}\text { Balio } \\
\text { optimoak }\end{array}$ \\
\hline Presioa (mbar) & $140-320$ & 185 & $56-200$ & 77 \\
Bibrazioa (Hz) & $100-2000$ & 1525 & $100-1500$ & 1150 \\
Tentsioa (V) & $250-2000$ & 1565 & $500-2000$ & 2000 \\
Distantzia (mm) & $30-150$ & 120 & $30-150$ & 60 \\
\hline
\end{tabular}
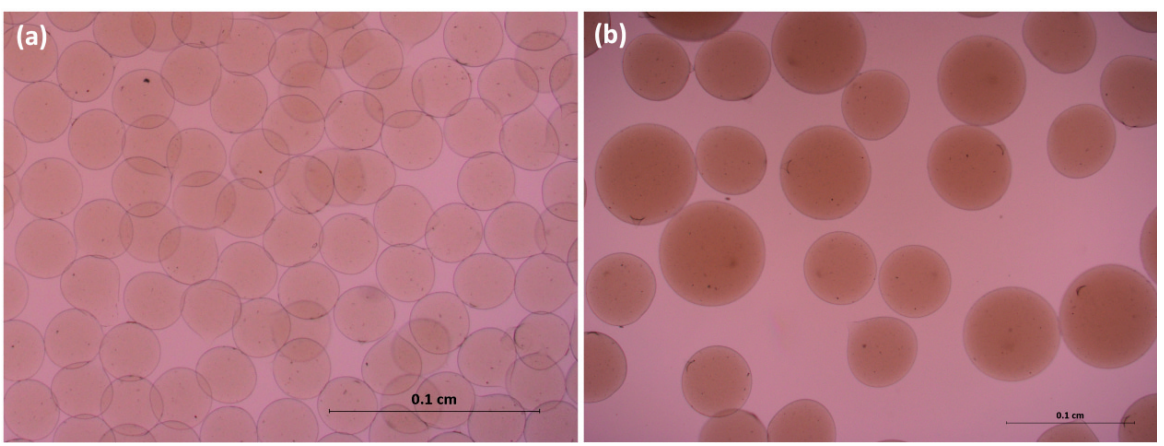

3. irudia. Mikroskopio optiko bidez ateratako mikrokapsulen argazkiak. (a) $150 \mu \mathrm{m}$-ko zurrustarekin baldintza optimoetan lortutako kapsulak. (b) $300 \mu \mathrm{m}$-ko zurrustarekin baldintza optimoetan lortutako kapsulak.

\subsection{Mikrokapsulen egonkonkortasun-azterketa}

Baldintza optimoetan erdietsitako mikrokapsulak liofilizazio bidez lehortu eta haien egonkortasuna aztertu da zenbait baldintzatan $\left(4^{\circ} \mathrm{C}\right.$-ra ilunpean eta giro-tenperaturan ilunpean eta argipean) 6 hilabetean zehar. Horretarako, ardo hondakinetako polifenol nagusiak diren katekinaren eta epikatekinaren kontzentrazioak neurtu dira kapsuletan azterketa osoan zehar eta emaitzei zentzua eman ahal izateko kapsulatu gabeko erauzkin berdinaren jarraipena ere egin da.

4. irudian dago erakusgai baldintza ezberdinetan kapsulek jasandako kontzentrazioen bilakaera. 3. taulan azaltzen dira mikrokapsulen eta kapsulatu gabeko erauzkinaren bizitza erdiak, hots, kontzentrazioak hasierako kontzentrazioaren erdira jaisteko kasu bakoitzean behar diren denborak. 
Oier Aizpurua-Olaizola, Asier Vallejo, Maitane Olivares, Patricia Navarro, Nestor Etxebarria, Aresatz Usobiaga
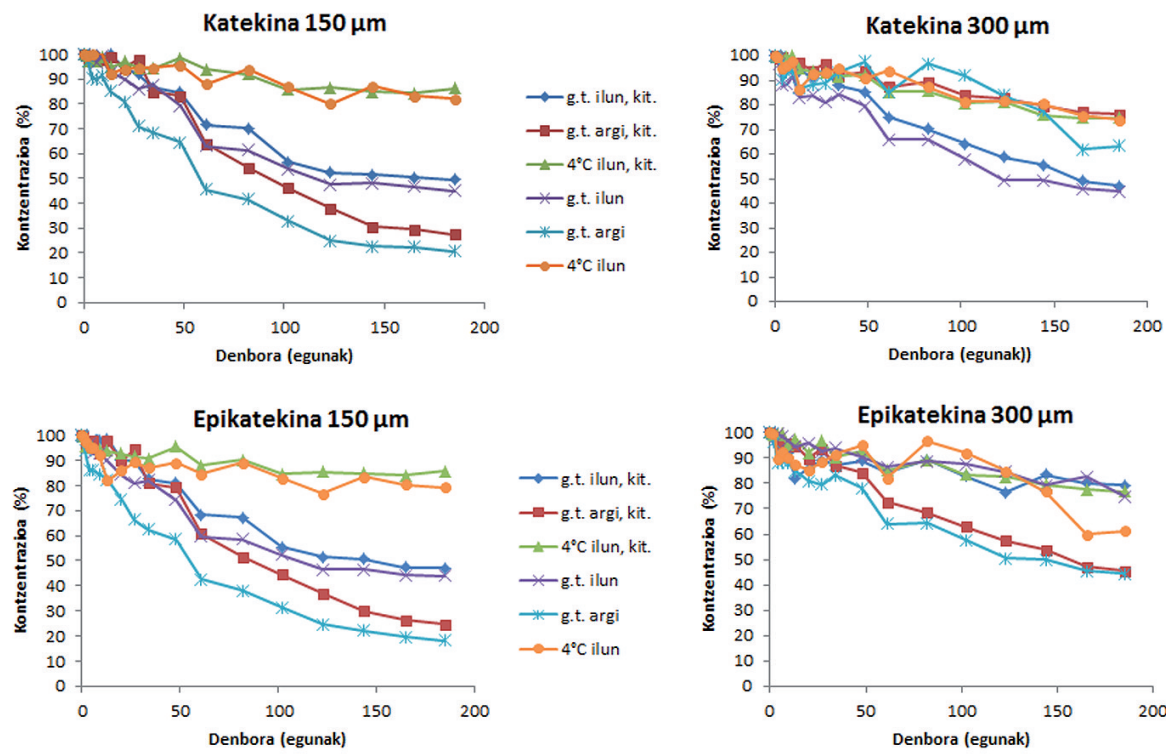

4. irudia. Katekina eta epikatekinaren egonkortasuna 150 eta $300 \mu$ m-ko zurrustekin osatutako mikrokapsuletan kitosana (kit.) erabiliz edo kitosanik gabe. Baldintzak bestalde, honakoak dira: $4^{\circ} \mathrm{C}$-ra hozkailuan ilunpean eta giro-tenperaturan (g.t.) ilunpean eta argipean $(n=3)$. Desbiderapenak \% 10etik beherakoak izan dira kasu guztietan.

4. irudian ikus daitekeenez, katekinak eta epikatekinak antzerako degradazio-abiadura mantentzen dute kasu guztietan, txikiena tenperatura baxuetan delarik. Bestetik, ikusi da Kitosana gehigarri gisa erabiltzeak degradazioa apur bat mantsotzen duela, hain zuzen $150 \mu \mathrm{m}$-ko zurrustarekin $\%$ 3-7 artean eta $300 \mu$ m-koarekin \% 1-16 artean. Bestalde, nahiz eta $4{ }^{\circ} \mathrm{C}$ ra joera hau ez sumatu, orokorrean mikrokapsula txikienak azkarrago degradatzen direla ikusi da, ziurrenik inguruarekin kontaktuan duten gainazalaren azalera handiagoa dutelako.

3. taulan argi ikus daitekeen bezala, orokorrean eta laburbilduz esan daiteke kapsulatutako erauzkina baino askoz ere azkarrago degradatzen dela kapsulatu gabeko erauzkina, baldintza guztietan. Giro-tenperaturan gordetzen direnean 5-33 aldiz azkarrago degradatzen da kapsulatu gabeko erauzkina, eta hozkailuan gordetzen direnean aldiz 1.2-2.1 aldiz azkarrago. 
3. taula. Kapsulatu gabeko erauzkineko eta erauzkin berdinarekin sortutako mikrokapsula ezberdinetako katekinaren eta epikatekinaren bizitza erdiak, baldintza ezberdinak ezarrita: kitosana (kit); giro-tenperatura (g.t).

\begin{tabular}{|c|c|c|c|}
\hline & \multirow{2}{*}{ Baldintzak } & \multicolumn{2}{|c|}{$t_{(1 / 2)}$ (egunak) } \\
\hline & & Katekina & Epikatekina \\
\hline \multirow{3}{*}{ Erauzkin askea } & $4^{\circ} \mathrm{C}$ & 396 & 408 \\
\hline & g.t. argi & 14 & 15 \\
\hline & g.t. ilun & 19 & 20 \\
\hline \multirow{3}{*}{$150 \mu \mathrm{m}$, kit. } & $4^{\circ} \mathrm{C}$ & 764 & 857 \\
\hline & g.t. argi & 89 & 85 \\
\hline & g.t. ilun & 152 & 146 \\
\hline \multirow{3}{*}{$150 \mu \mathrm{m}$, kit. ez } & $4^{\circ} \mathrm{C}$ & 619 & 680 \\
\hline & g.t. argi & 74 & 72 \\
\hline & g.t. ilun & 139 & 139 \\
\hline \multirow{3}{*}{$300 \mu \mathrm{m}$, kit. } & $4^{\circ} \mathrm{C}$ & 478 & 510 \\
\hline & g.t. argi & 462 & 478 \\
\hline & g.t. ilun & 163 & 157 \\
\hline \multirow{3}{*}{$300 \mu \mathrm{m}$, kit. ez } & $4^{\circ} \mathrm{C}$ & 472 & 465 \\
\hline & g.t. argi & 373 & 361 \\
\hline & g.t. ilun & 157 & 159 \\
\hline
\end{tabular}

\section{ONDORIOAK}

Ardo hondakinetatik gantz azido asegabeak eta polifenolak bereizita erauzteko SFE metodoa garatu da. Garatutako metodoa azkarra da, eta gainera, konposatu aktiboen degradazioa ekiditen du, tenperatura baxue$\tan \left(35^{\circ} \mathrm{C}\right)$ egiten delako. Bestalde, polifenolak erraz degrada daitekeenez, polifenol hauek kapsulatzeko metodo bat garatu da VNM bidez. Janari-esparruko aplikazio ezberdinetarako egokiak izan daitezkeen alginato mikrokapsulak garatu dira, hainbat tamainatakoak. Horrela, sortutako mikrokapsulek izugarri hobetu dute polifenolen egonkortasuna. Kitosana gehigarri gisa erabiltzeko aukera aztertu da eta egonkortasuna are gehiago hobetzen duela ikusi da.

Laburbilduz, lan honen bidez ardo hondakinetatik bi produktu interesgarri erdietsi direla esan daiteke: batetik gantz azido asegabeetan oso aberatsa den erauzkina eta bestetik egonkortasun handiko polifenol-mikro- 
Oier Aizpurua-Olaizola, Asier Vallejo, Maitane Olivares, Patricia Navarro, Nestor Etxebarria, Aresatz Usobiaga

kapsulak. Modu honetan ardo hondakinen balioa handitzea lor daiteke, eta Euskal Herrian sortzen den bolumena zenbatekoa den kontuan hartuz, litekeena da bera izatea etorkizun hurbileko aukera. Arrazoia izango du azkenean hondakinak txerrikeria bat direla dioenak, kasu honetan ere, txerriarenean bezala, dena baita erabilgarria.

\section{ESKER ONAK}

Egileek esker ona adierazi nahi diete IDOKI SCF S.L. enpresari jariakin gainkritiko bidezko erauzketa sistema erabiltzen uzteagatik, Ostatu eta Mokoroaga ardotegiei ikerketarako beharrezko materiala eskaintzeagatik eta Eusko Jaurlaritzari SAIOTEK (SAI12/136) egitasmoagatik. O. Aizpuruak esker onak adierazi nahi dizkio Eusko Jaurlaritzari, baita bere aurredoktoradutzako bekarengatik.

\section{BIBLIOGRAFIA}

[1] SHAHIDI F. 2012. «Nutraceuticals, functional foods and dietary supplements in health and disease». J Food Drug Anal, 20, 226-230.

[2] DUGAS A.J., CASTAÑEDA-ACOSTA J., BONIN G.C., PRICE K.L., FISHER N.H. eta WINSTON G.W. 2000. «Evaluation of the total peroxyl radical-scavenging capacity of flavonoids: structure-activity relationships». J Nat Prod, 63, 327-331.

[3] TIKHONOV I., ROGINSKY V. eta PLISS E. 2009. «The chain-breaking antioxidant activity of phenolic compounds with different numbers of $\mathrm{O}-\mathrm{H}$ groups as determined during the oxidation of styrene». Int J Chem Kinet, $\mathbf{4 1}$, 92-100.

[4] LEOPOLDINI M., RUSSO N. eta TOSCANO M. 2011. «The molecular basis of working mechanism of natural polyphenolic antioxidants». Food Chem, 125, 288-306.

[5] KIM J., LEE K.W eta LEE H.J. 2014. «Polyphenols suppress and modulate inflammation: Possible Roles in Health and Disease». In WATSON R.R., PREEDY V.R., ZIBADI S., (Eds.), «Polyphenols in Human Health and Disease». Academic Press, Massachusetts, USA, 393-408 orr.

[6] HERTOG M.G.L. 1994. «Flavonols and Flavones in Foods and Their Relation with Cancer and Coronary Heart Disease Risk». Ph.D. Thesis, The Netherlands: Agricultural University Wageningen.

[7] CORDOVA, F.M. eta WATSON, R.R. (2014). «Food and supplement polyphenol action in cancer recurrence». In WATSON, R.R., PREEDY, V.R., \& ZIBADI, S., (Eds.), «Polyphenols in Human Health and Disease». Academic Press, Massachusetts, USA, 191-195 orr. 
[8] JEAN-GILLES D., LI I., VAIDYANATHAN V.G., KING R., CHO B., WORTHEN D.R, CHICHESTER C.O. eta SEERAM N.P. 2013. «Inhibitory effects of polyphenol punicalagin on type-II collagen degradation in vitro and inflammation in vivo». Chem Biol Interact, 205, 90-99.

[9] MENAA, F. eta MENAA, A. 2014. «Skin photoprotection by polyphenols in animal models and humans». In WATSON, R.R., PREEDY, V.R., \& ZIBADI, S., (Eds.), «Polyphenols in Human Health and Disease». Academic Press, Massachusetts, USA, 831-838 orr.

[10] PAPANDREOU M.A., DIMAKOPOULOU A., LINARDAKI Z.I., CORDOPATIS P., KLIMIS-ZACAS D., MARGARITY M. eta LAMARI F.N. 2009. «Effect of a polyphenol-rich wild blueberry extract on cognitive performance of mice, brain antioxidant markers and acetylcholinesterase activity». Behav Brain Res, 198, 352-358.

[11] FEDAČKO J., PELLA D., MECHÍROVÁ V., HORVATH P., RYBÁR R., VARJASSYOVÁ P. eta VARGOVÁ V. 2007. «N-3 PUFAs From dietary supplements to medicines». Pathophysiology, 14, 127-132.

[12] TOUSOULIS D., PLASTIRAS A., SIASOS G., OIKONOMOU E., VERGENIOTIS A., KOKKOU E. eta STEFANADIS C. 2014. «Omega-3 PUFAs improved endothelial function and arterial stiffness with a parallel antiinflammatory effect in adults with metabolic syndrome». Atherosclerosis, 232, $10-16$.

[13] STEIN O., DABACH Y., BEN-NAIM M., HALPERIN G. eta STEIN Y. 2008. «Effects of oleic acid and macrophage recruitment on cholesterol efflux in cell culture and in vivo». Nutr Metab Cardiovasc Dis, 18, 596-601.

[14] GNONI G.V., NATALI F., GEELEN M.J.H eta SICULELLA L. 2010. «Oleic acid as an inhibitor of fatty acid and cholesterol synthesis». In PREEDY V.R., WATSON R.R., (Eds.), «Olives and olive oil in health and disease prevention». Academic Press, Massachusetts, USA, 13651373 orr.

[15] MENSINK R.P. «Fatty Acids: health effects of saturated fatty acids». 2013. In ALLEN L.H., PRENTICE A., CABALLERO B., (Eds.), «Encyclopedia of Human Nutrition». Academic Press, Massachusetts, USA, 215-219 orr.

[16] AIZPURUA-OLAIZOLA, O., ORMAZABAL, M., VALLEJO, A., OLIVARES, M., NAVARRO, P., ETXEBARRIA, N. eta USOBIAGA, A. 2015. «Optimization of supercritical fluid consecutive extractions of fatty acids and polyphenols from Vitis Vinifera grape wastes». J Food Sci, 80, 101-107.

[17] RAVENTÓS, M., DUARTE, S. eta ALARCÓN, R. 2002. «Application and Possibilities of Supercritical CO2 Extraction in Food Processing Industry: An Overview». Food Sci Tech Int, 8, 269-284.

[18] SAHENA, F., ZAIDUL, I.S.M., JINAP, S., KARIM, A.A., ABBAS, K.A., NORULAINI, N.A.N. eta OMAR, A.K.M. 2009. «Application of supercritical CO2 in lipid extraction - A review». J Food Engineer, 95, 240-253.

[19] MENDIOLA, J.A., HERRERO, M., CASTRO-PUYANA, M. eta IBAÑEZ, E. 2013. «Supercritical Fluid Extraction». In ROSTAGNO, M.A., PRADO, 
Oier Aizpurua-Olaizola, Asier Vallejo, Maitane Olivares, Patricia Navarro, Nestor Etxebarria, Aresatz Usobiaga

J.M., (Eds.), «Natural Products Extraction». Royal Society of Chemistry, London, UK, 196-230 orr.

[20] CHAUDOT, X., TAMBUTÉ, A. eta CAUDE., M. 2000. «Selective extraction of hydrocarbons, phosphonates and phosphonic acids from soils by successive supercritical fluid and pressurized liquid extractions». J Chromatogr A, 866, 231-240.

[21] OMAR, J., ALONSO, I., GARAIKOETXEA, A. eta ETXEBARRIA, N. 2013. «Optimization of focused ultrasound extraction (FUSE) and supercritical fluid extraction (SFE) of citrus peel volatile oils and antioxidants». Food Anal Meth, 6, 1244-1252.

[22] BAKOWSKA, A.M., KUCHARSKA, A.Z. eta OSZMIANSKI, J. 2003. «The effects of heating, UV irradiation and storage on stability of anthocyanin-polyphenol copigment complex». Food Chem, 81, 349-355.

[23] MUNIN, A. eta EDWARDS-LÉVY, F. 2011. «Encapsulation of Natural Polyphenolic Compounds; a Review». Pharmaceutics, 3, 793-829.

[24] AIZPURUA-OLAIZOLA , O., NAVARRO, P., VALLEJO, A., OLIVARES, M., ETXEBARRIA, N. eta USOBIAGA, A. 2016. «Microencapsulation and storage stability of polyphenols from Vitis vinifera grape wastes». Food Chem, 190, 614-621.

[25] DORATI, R., GENTA, I., MODENA, T. eta CONTI, B. 2013. «Microencapsulation of a hydrophilic model molecule through vibration nozzle and emulsion phase inversion technologies». J Microencap, 30, 559-570.

[26] KING, A.H. 1983. «Brown Seaweed Extracts (Alginates)». In M. GLICKSMAN (Ed). «Food Hydrocolloids». Boca Raton, FL: CRC Press, 115 orr.

[27] KRASAEKOOPT, W., BHANDARI, B. eta DEETH, H. 2003. «Evaluation of encapsulation techniques of probiotics for yoghurt». Int Dairy J, 13, 3-13.

[28] XU, Y., ZHAN, C., FAN, L., WANG, L. eta ZHENG, H. 2007. «Preparation of dual crosslinked alginate-chitosan blend gel beads and in vitro controlled release in oral site-specific drug delivery system». Int J Pharmaceut, 336, 329-337.

[29] SINGLETON, V.L. eta ROSSI, J.A. 1965. «Colorimetry of total phenolics with phospho-molybdic-phosphotungstic acid reagents». Am J Enol Viticult, 16, 144-158. 